University of Nebraska - Lincoln

DigitalCommons@University of Nebraska - Lincoln

Faculty Papers and Publications in Animal

Science

Animal Science Department

October 1989

\title{
INDEX SELECTION FOR COMPONENTS OF LITTER SIZE IN SWINE: RESPONSE TO FIVE GENERATIONS OF SELECTION
}

\author{
S. M. Neal \\ University of Nebraska-Lincoln \\ R. K. Johnson \\ University of Nebraska-Lincoln, rjohnson5@unl.edu \\ R. J. Kittock \\ University of Nebraska-Lincoln
}

Follow this and additional works at: https://digitalcommons.unl.edu/animalscifacpub

Part of the Animal Sciences Commons

Neal, S. M.; Johnson, R. K.; and Kittock, R. J., "INDEX SELECTION FOR COMPONENTS OF LITTER SIZE IN SWINE: RESPONSE TO FIVE GENERATIONS OF SELECTION" (1989). Faculty Papers and Publications in Animal Science. 87.

https://digitalcommons.unl.edu/animalscifacpub/87

This Article is brought to you for free and open access by the Animal Science Department at DigitalCommons@University of Nebraska - Lincoln. It has been accepted for inclusion in Faculty Papers and Publications in Animal Science by an authorized administrator of DigitalCommons@University of Nebraska - Lincoln. 
Published in Journal of Animal Science, 67 (1989), pp.1933-1945. Copyright (C) 1989 American Society of Animal Science. Used by permission.

\title{
Index Selection for Components of Litter Size in Swine: Response to Five Generations of Selection
}

\author{
S. M. Neal, Agric. Tech. Inst., The Ohio State Univ., Wooster \\ R. K. Johnson, Animal Science Dept., Univ. of Nebraska-Lincoln \\ R. J. Kittok, Animal Science Dept., Univ. of Nebraska-Lincoln
}

\begin{abstract}
Selection for an index of ovulation rate (OR) and embryo (fetal) survival rate (ES) to $50 \mathrm{~d}$ of gestation (I = $10.6 \times \mathrm{OR}+72.6 \times \mathrm{ES}$ ) was practiced for five generations in a line that was a composite population of the Large White and Landrace breeds of swine. A control line sampled from the same population was selected randomly and mated. Ovulation rate and number of fetuses (FETS) were measured by laparotomy and ES was calculated as FETS/OR. The select line averaged 43 litters by 18 sires and the control line averaged 42 litters by 15 sires per generation. Each generation, all females available in the select line (average of 147) were mated and laparotomized, but only selected females were farrowed. One-half of the females underwent laparotomy in the control line. Inbreeding coefficients at generation five averaged $5.34 \%$ for the select line and $4.59 \%$ for the control line. Regressions of the difference between means of the lines on generation number were $.57 \pm .11$ for OR, $-.013 \pm .0096$ for ES, $.20 \pm .20$ for FETS and $5.10 \pm 1.76$ for I. Realized heritability for I was $.30 \pm .09$. Heritabilities estimated by regression of daughter on dam were .17 \pm .07 for OR, $.18 \pm .09$ for ES and $.08 \pm .10$ for FETS, and the genetic correlation between OR and ES was estimated to be $-.56 \pm .24$. The increase in number of pigs per litter at birth was $.19 \pm .14$ per generation.
\end{abstract}




\title{
INDEX SELECTION FOR COMPONENTS OF LITTER SIZE IN SWINE: RESPONSE TO FIVE GENERATIONS OF SELECTION1
}

\author{
S. M. Neal ${ }^{2}$, R. K. Johnson ${ }^{3}$ and R. J. Kittok ${ }^{3}$ \\ University of Nebraska \\ Lincoln 68583-0908
}

\begin{abstract}
Selection for an index of ovulation rate (OR) and embryo (fetal) survival rate (ES) to 50 d of gestation ( $I=10.6 \times O R+72.6 \times E S)$ was practiced for five generations in a line that was a composite population of the Large White and Landrace breeds of swine. A control line sampled from the same population was selected randomly and mated. Ovulation rate and number of fetuses (FETS) were measured by laparotomy and ES was calculated as FETS/OR. The select line averaged 43 litters by 18 sires and the control line averaged 42 litters by 15 sires per generation. Each generation, all females available in the select line (average of 147) were mated and laparotomized, but only selected females were farrowed. One-half of the females underwent laparotomy in the control line. Inbreeding coefficients at generation five averaged $5.34 \%$ for the select line and $4.59 \%$ for the control line. Regressions of the difference between means of the lines on generation number were $.57 \pm .11$ for OR, $-.013 \pm .0096$ for ES, .20 \pm .20 for FETS and $5.10 \pm 1.76$ for 1 . Realized heritability for I was $.30 \pm .09$. Heritabilities estimated by regression of daughter on dam were $.17 \pm .07$ for OR, $.18 \pm .09$ for ES and $.08 \pm .10$ for FETS, and the genetic correlation between $\mathrm{OR}$ and ES was estimated to be $-.56 \pm .24$. The increase in number of pigs per litter at birth was $.19 \pm .14$ per generation.
\end{abstract}

(Key Words: Pigs, Reproduction, Litter Size, Selection Index, Ovulation, Embryo Mortality.)

J. Anim. Sci. 1989. 67:1933-1945

\section{Introduction}

Increasing litter size will improve efficiency of swine production (Tess et al., 1983). Genetic selection for litter size has been relatively unsuccessful (Rutledge, 1980; Ollivier, 1982). This has stimulated research into ways to improve litter size by selection for ovulation rate, uterine capacity and survival rate of embryos (Johnson et al., 1984; Leymaster et al., 1986).

\footnotetext{
${ }^{1}$ Published as paper No. 8719, Journal Series, Agric. Res. Div., Univ. of Nebraska, Lincoln. Appreciation is expressed to B. Van Pelt, W. R. Lamberson, S. Sasaki, Y. T. Huang, G. R. Eckardt, T. E. Long and G. A. Bussler for assistance in collection of data. 44691 .

${ }^{2}$ Agric. Tech. Inst., The Ohio State Univ., Wooster

${ }^{3}$ Anim. Sci. Dept., Univ. of Nebraska, Lincoln.

Received September 1, 1988.

Accepted January 30, 1989.
}

Research with mice (Bradford, 1969; Land and Falconer, 1969) and swine (Zimmerman and Cunningham, 1975; Cunningham et al., 1979) has demonstrated that ovulation rate responded to direct selection, but this selection was not very effective in changing litter size. However, Bradford (1969) found that selection for survival rate of embryos and fetuses (number of normal fetuses at $16 \mathrm{~d}$ of gestation, as a ratio to number of corpora lutea, the ratio weighted by number of fetuses) was effective and resulted in larger litter sizes at birth in mice.

Results of these experiments led us to initiate selection for litter size based on an index of ovulation rate and embryo survival to $50 \mathrm{~d}$ of gestation. The objectives of this paper are to describe this experiment, to summarize response to five generations of selection and to estimate phenotypic and genetic parameters for traits that are components of litter size. 
TABLE 1. DESCRIPTIVE STATISTICS FOR LITTER SIZE BEFORE AND AFTER STANDARDIZATION OF LITTER SIZE AT BIRTH

\begin{tabular}{|c|c|c|c|c|c|c|c|}
\hline Generation & Line $^{a}$ & $\mathbf{N}^{\mathbf{b}}$ & $\begin{array}{l}\text { No. born } \\
\text { alive }\end{array}$ & SD & $\mathbf{N}^{\mathrm{c}}$ & $\begin{array}{l}\text { No. after } \\
\text { transfer }\end{array}$ & SD \\
\hline \multirow[t]{2}{*}{0} & LSI & 42 & 9.86 & 2.25 & 42 & 10.09 & 2.12 \\
\hline & C & 41 & 9.32 & 2.64 & 40 & 9.40 & 2.59 \\
\hline \multirow[t]{2}{*}{1} & LSI & 43 & 10.49 & 2.14 & 43 & 10.56 & 1.67 \\
\hline & C & 40 & 10.20 & 2.50 & 41 & 10.20 & 2.23 \\
\hline \multirow[t]{2}{*}{2} & LSI & 43 & 10.28 & 2.28 & 43 & 10.23 & 2.23 \\
\hline & C & 40 & 8.80 & 3.00 & 39 & 9.03 & 2.19 \\
\hline \multirow[t]{2}{*}{3} & LSI & 44 & 9.70 & 2.45 & 44 & 9.64 & 1.70 \\
\hline & C & 40 & 8.80 & 2.56 & 40 & 8.88 & 2.36 \\
\hline \multirow[t]{2}{*}{4} & LSI & 43 & 9.36 & 2.89 & 44 & 9.55 & 2.10 \\
\hline & $\mathrm{C}$ & 41 & 8.20 & 3.20 & 41 & 8.34 & 2.88 \\
\hline \multirow[t]{2}{*}{5} & LSI & 41 & 9.78 & 2.74 & 39 & 9.69 & 2.28 \\
\hline & C & 43 & 8.58 & 2.86 & 43 & 9.42 & 2.30 \\
\hline
\end{tabular}

${ }^{\mathrm{a}} \mathrm{LSI}=$ select line, $\mathrm{C}=$ control line.

${ }^{b} \mathrm{~N}$ includes only femaies that farrowed at least one live piglet.

${ }^{c}$ Discrepancies in $\mathbf{N}$ before and after transfer were the result of nurse dams rearing a litter in addition to their own or to some cross-fostering across these two lines and a third line that was part of this population, but is not included in this paper.

\section{Materials and Methods}

Purebred Landrace and Large White pigs were obtained in 1976 and maintained as pure lines until 1978, when they were crossed. The $F_{1}$ and $F_{2}$ generations were mated randomly ( 55 gilts and 20 boars per generation). Pigs of the $F_{3}$ generation were assigned randomly within litter to select (LSI) and control (C) lines. Selection was initiated in 1981 based on an index of ovulation rate (OR) and embryo (fetal) survival rate to $50 \mathrm{~d}$ of gestation (ES). The index was $(I)=10.6 \times$ OR $+72.6 \times$ ES. Johnson et al. (1984) present the theory for this approach to selection for litter size and give details of the construction of this index. Estimates of parameters for number of fetuses (FETS) at $50 \mathrm{~d}$ of gestation were not available. Thus, estimates for total number of fully formed piglets per litter (TNB) were used to construct the index. A genetic correlation of 1 was assumed between number at $50 \mathrm{~d}$ and TNB, so TNB is the aggregate genotype to be improved.

Each generation, all female progeny in line LSI, an average of 147 , were mated to approximately 20 sons of the 15 highest indexing dams. Laparotomy was performed at $50 \mathrm{~d}$ of gestation. The highest indexing females were selected and farrowed. The line averaged 43 litters by 18 sires per generation. The remaining females were culled before parturition.

Approximately 55 gilts, at least one per litter, were chosen randomly each generation in the control line. These were mated to 15 males that were selected at random, one from each half-sib family. The control line averaged 42 litters by 15 sires per generation. One-half of these underwent laparotomy to allow estimation of the effects of the surgical procedure on survival rate of fetuses after $50 \mathrm{~d}$ of gestation and on litter size at birth. Hereafter these will be referred to as CL to distinguish them from females in the control line that were not laparotomized, which are denoted as C. All pregnant females in the control line were farrowed.

Total number of fully formed piglets (TNB), number of live piglets (NBA) and number of mummified piglets (MUMM) were recorded at birth of litters. Cross-fostering was done to standardize size of litter reared by each dam, but it was not possible to do this precisely. An attempt was made to reduce the size of larger litters to no more than 10 piglets. Descriptive statistics for litter size before and after transfer of piglets among litters are given in Table 1.

Pigs were weaned at $28 \mathrm{~d}$ of age and reared in single-sex groups of 25 in raised-deck nursery pens. Weanling pigs were fed a pelleted diet formulated to contain $18 \%$ protein. At about $56 \mathrm{~d}$ of age, pigs were moved to modified open-front buildings, where they were housed separately by sex in groups of 10 head per pen. They were fed a diet formulated to contain $16 \%$ protein until they reached a BW of about $57 \mathrm{~kg}$ and were fed a $14 \%$ protein diet thereafter. 
Estrus was detected by daily exposure of gilts to intact boars to determine age at puberty. Exposure to boars began for all gilts in a pen when the oldest gilt was $135 \mathrm{~d}$ of age in generations zero and one, and $130 \mathrm{~d}$ in all other generations. The range in age at puberty for each line in each generation is given in Table 2.

Matings among selected boars and gilts were random except that full- and half-sib matings were avoided. Females were not mated until estrus had been expressed at least twice, with the exception of six gilts in generations one and two that were mated at their first estrus. Only a sample of the females was observed for age at puberty in generation zero, and some of those not observed could have been mated at their first estrus. Females were mated to farrow at an average age of 1 yr. Gilts gestated in individual crates. The number of days between age at puberty and mating varied widely within generations, but most females were mated at their third or fourth estrus (Table 2). The number of females at each stage of the production cycle is summarized in Table 2 .

Laparotomy was performed at $50 \mathrm{~d}$ of gestation on all females in the select line. No females in the control line were laparotomized in generation zero, one-half were laparotomized in generations one through four and all were laparotomized in generation five. Females were immobilized with thiamylal sodium $(8.8 \mathrm{mg} / \mathrm{kg} \mathrm{BW}$, i.v.) and anesthesia was maintained by inhalation of a mixture of 1,500 $\mathrm{ml} / \mathrm{min}$ oxygen, $100 \mathrm{ml} / \mathrm{min}$ nitrous oxide and $50 \mathrm{ml} / \mathrm{min}$ halothane. Flow of nitrous oxide was reduced throughout surgery to a level of $20 \mathrm{ml} / \mathrm{min}$.

The reproductive tract was exposed through a midventral incision in the abdominal wall. Ovaries and uterus were externalized, corpora lutea on both ovaries were counted and the uterus was palpated to count number of fetuses. A sterile field was maintained during surgery and sterile saline $(.9 \% \mathrm{NaCl})$ was used to moisten the tract.

The traits OR, FETS, ES and I at $50 \mathrm{~d}$ of gestation were available for all LSI and CL gilts. Resorption of fetuses between $50 \mathrm{~d}$ of gestation and parturition (LOSS) was estimated as LOSS = FETS - TNB - MUMM. Females in the control line in generation zero were littermates to those in the select line, and means for the lines were assumed to be equal.
Selection of replacement gilts and boars was based on their dam's index. Realized selection differentials for females were calculated by weighting the selection differential on each female by the number of daughters measured in the subsequent generation. These were averaged, with the divisor being the total number of gilts measured in the next generation, to obtain $F$, the mean female selection differential. Response to male selection lags by one generation. Selection differentials for males were calculated by weighting the selection differential for the dam of each selected male by the number of his daughters measured in the subsequent generation, and $M$, the average weighted selection differential for males, was calculated. Cumulative selection differentials for generation $\mathrm{n}$ were calculated as:

$$
\mathrm{CSD}_{\mathrm{n}}=\sum_{\mathrm{i}=0}^{\mathrm{n}-2} .25\left(\mathrm{M}_{\mathrm{i}}+\mathrm{F}_{\mathrm{i}}\right)+.5 \mathrm{~F}_{\mathrm{n}-1} \text {, }
$$

where $\mathrm{M}$ and $\mathrm{F}$ are selection differentials of dams of selected males and females, respectively, in generation $n, n=0$ to 5 .

The proportion of the expected selection differential that was realized was calculated for each generation to evaluate the joint effects of laparotomy and natural selection on the selection differential. Expected selection differentials were calculated by ranking individuals on their index and those with the highest ranks up to the number actually selected were assumed to have been selected. Sires were assumed to have been mated to an equal number of females, and each mating was assumed to have produced an equal number of progeny.

Response to selection for each trait was calculated as the regression of the deviation of the mean of the select line from the mean of the control line each generation on generation number. Deviations for OR, ES, FETS and I also were regressed on the cumulative selection differential of the index. Regression coefficients of differences between lines for OR, ES, FETS and I were calculated by weighted least squares procedures. The weighting factor was the number of observations per line in each generation. The statistical model (Richardson et al., 1968) was:

$$
n_{i j} Y_{i j}=a .+g_{\cdot j}+B n_{i j} Z_{i j}+E_{i j}
$$


NEAL ET AL.

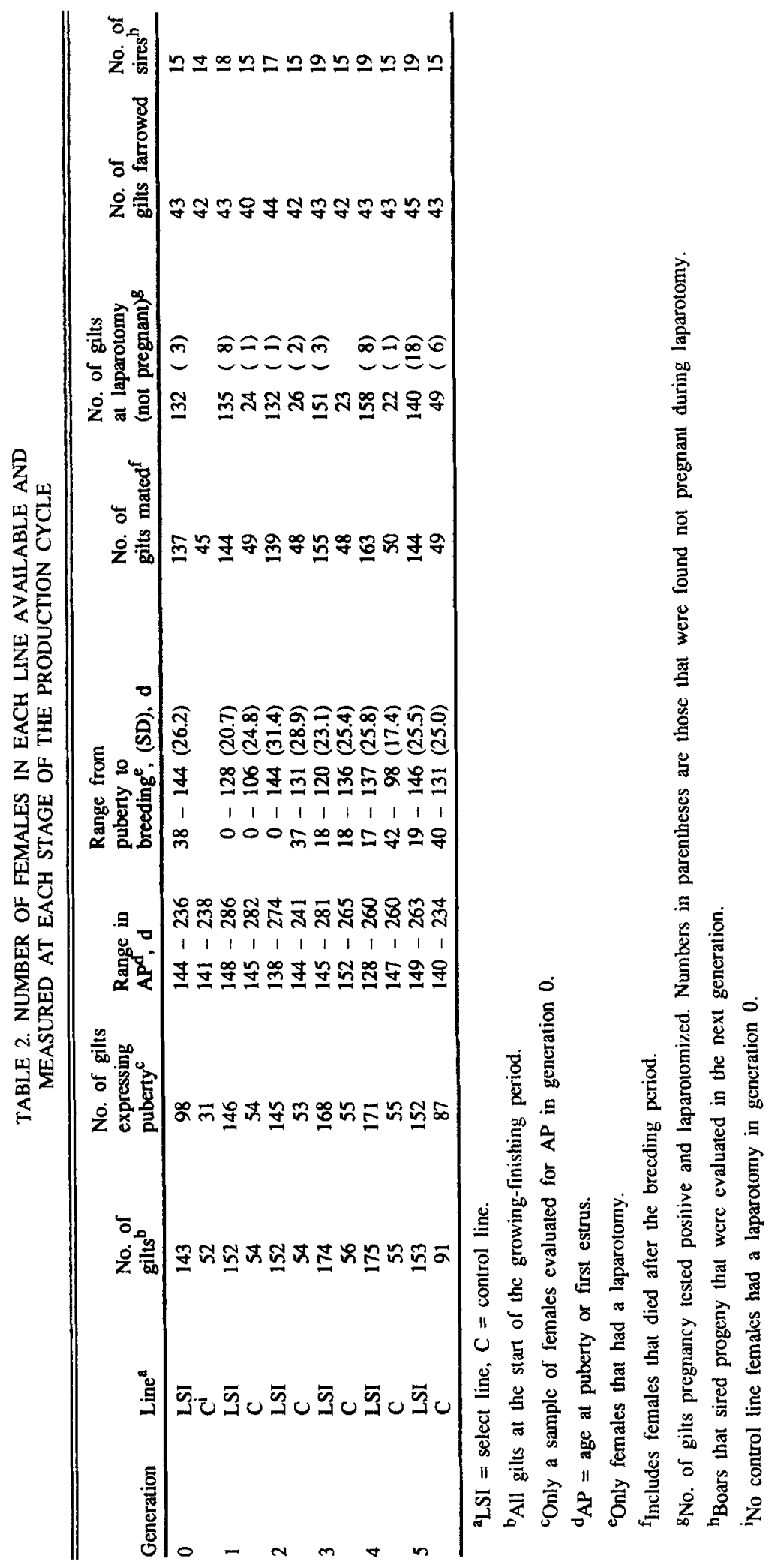


where:

$Y_{i j}=$ mean for the $j^{\text {th }}$ generation of the $\mathrm{i}^{\text {th }}$ line,

$n_{i j}=$ number of observations in the mean for the $\mathrm{j}^{\text {th }}$ generation of the $\mathrm{i}^{\text {th }}$ line,

a. . = the expected performance of the base population,

$g_{\cdot j}=$ the environmental effect common to each line in the $\mathrm{j}^{\text {th }}$ generation,

$B=$ the linear regression coefficient on the cumulative selection differential $\left(Z_{i j}\right)$ of the $i^{\text {th }}$ line in the $j^{\text {th }}$ generation, and

$E_{i j}=$ random error.

Control line females were not evaluated in generation zero, and only one-half of them were evaluated in generations one through four. Thus, cumulative selection differentials for the control line could not be estimated precisely and were set to zero. In the formula above, selection differentials were halved to account for the fact that selection was on the dam's record and realized heritability of I was equal to the regression coefficient B. Standard errors of the regression coefficients were corrected for genetic drift variance as described by Hill $(1972,1974,1977)$ and Notter et al. (1976).

Realized genetic correlations of OR, ES and FETS with the index were calculated using the following formula:

$$
r_{g_{y, I}}=\frac{B_{y, I} h_{I} o_{I}}{h_{y} \delta_{y}},
$$

where:

$$
\begin{aligned}
B_{y, I}= & \text { regression coefficient of the } \\
& \text { difference between means of } \\
& \text { the select and control line for } \\
& \text { trait y on differences for the in- } \\
& \text { dex, weighted by the number of } \\
& \text { observations per generation, } \\
\mathrm{h}= & \text { square root of heritability (real- } \\
& \text { ized heritability for the index } \\
& \text { and the estimate from daugh- } \\
& \text { ter-dam regression for trait } y)
\end{aligned}
$$

$$
\begin{array}{r}
o=\text { pooled within generation and } \\
\text { line phenotypic standard devia- } \\
\text { tion for the index or for trait } y .
\end{array}
$$

Regressions of daughter's record on dam's record, pooled within generation and line, also were used to estimate genetic parameters of OR, ES, FETS and I. Reciprocal daughter-dam regression were calculated, and genetic correlations were estimated as:

$$
r_{g_{x, y}}=\sqrt{\frac{B_{x, y^{\prime}} \cdot B_{y, x^{\prime}}}{B_{x, x^{\prime}} \cdot B_{y, y^{\prime}}}}
$$

where:

$$
\begin{aligned}
x= & \text { trait } x \text { measured on the daugh- } \\
& \text { ter, } \\
x^{\prime}= & \text { trait } x \text { measured on the dam, } \\
y= & \text { trait } y \text { measured on the daugh- } \\
& \text { ter, and } \\
y^{\prime}= & \text { trait } y \text { measured on the dam. }
\end{aligned}
$$

Approximate standard errors for genetic correlations were calculated as follows (Falconer, 1981):

$$
\operatorname{SE}\left(r_{\mathbf{g}_{x, y}}\right)=\left({ }^{1-r^{2}} g_{x, y} \sqrt{\frac{S E\left(h^{2}\right) \cdot S E\left(h^{2}\right)}{2 h^{2} \cdot h_{y}^{2}}}\right.
$$

Linear and quadratic regressions of traits measured at $50 \mathrm{~d}$ of gestation on the interval between age at puberty and breeding were calculated with a model that included line and generation as fixed effects. These were used to adjust OR, ES, FETS and I to the average number of days from puberty to breeding. Genetic parameters were estimated for the adjusted records by reciprocal regression of daughter on dam and compared to those for unadjusted records.

\section{Results}

Means and standard deviations for OR, ES, FETS and I and the regression coefficients of differences between lines on generation number and on cumulative selection differential of the index are given in Table 3. Index and ovulation rate responded significantly to selection. After five generations, the lines differed 
in ovulation rate by 2.97 ova and 26.4 index points. Embryo (fetal) survival rate in the select line declined slightly each generation. The difference between the lines was $7 \%$ at generation five. The trend was positive for FETS, but was not significant; the lines differed by .98 fetuses at generation five. Fetal survival rate from $50 \mathrm{~d}$ of gestation to parturition (TNB/FETS) was consistently lower for line LSI and averaged $-.036 \pm .0103$ less than for line CL.

Realized selection differentials are presented in Table 4 and averaged 19.0 index points per generation. Realized heritability for

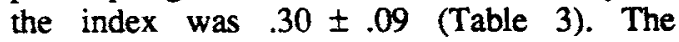
theoretical heritability of the index was calculated to be .35 based on the parameters presented by Johnson et al. (1984). Inbreeding coefficients used to calculate genetic drift variance and the standard error of the realized heritability were 5.3 and $4.6 \%$ for females in lines LSI and C, respectively, in generation five. Realized genetic correlations of OR, ES and FETS with the index were $1.28,-.04$ and 1.30 respectively.

Descriptive statistics for traits measured at parturition are presented in Table 5 . Regression coefficients of differences between lines on generation number were calculated for generations one to five because no line $C$ females were laparotomized in generation zero. The coefficients for LOSS, TNB and MUMM were not significant. However, over the five generations line LSI averaged more losses between $50 \mathrm{~d}$ of gestation and parturition than line $C(.61 \pm .09$ fetuses). At generation five, the difference between line LSI and CL was 2.4 fully formed piglets at birth. Litter size at birth did not increase significantly from selection for the index. However, mean TNB was not available for a random sample of females in line LSI. The average difference over generations between line LSI and all line $\mathrm{C}$ females was $1.04 \pm .17$ piglets, and the average difference between lines LSI and control line females that were laparotomized (CL) was $2.32 \pm .24$ piglets. The difference in total number born per litter between control line females that had no laparotomy and those that did averaged $1.2 \pm .4$ piglets for generations one through four. Mean number of mummified piglets also was different for laparotomized females in the select and control lines (average difference of $.5 \pm .06$ ). Howev$\mathrm{er}$, the magnitude of the difference did not change significantly during the experiment.

Estimates of genetic parameters obtained by daughter-dam regression are given in Table 6. Estimates of heritability for OR, ES, FETS and the index were $.17 \pm .08, .18 \pm .09$, $.08 \pm .10$ and $.12 \pm .09$, respectively. Ovulation rate was negatively correlated with both ES and FETS, and a moderately high correlation was found between ES and FETS.

The interval from age at puberty to breeding affected all traits measured at $50 \mathrm{~d}$ of gestation. The linear regression coefficient was significant for all traits and the quadratic coefficient approached significance for $O R$ and was significant for ES, FETS and I. However, the proportions of the within year-line sums of squares removed by regression $\left(R^{2}\right)$ was less than $3 \%$ for all traits. After adjustment, residual standard deviations were only slightly less than the pooled within year-line standard deviations. These relationships, expressed as the change in each trait with advancing estrous cycles before mating, are illustrated in Figures 1 through 4.

The majority of the matings in this experiment were at the third or fourth estrous cycle. Increases in OR from second.to third and from third to fourth cycle were .47 and .33 ova, respectively. Embryo survival rate increased $.26 \%$ when pregnancy occurred at the third estrus rather than the second, and decreased $1 \%$ from the third to fourth estrus. The index increased 5.43 points for gilts mated at the third rather than the second estrus and 2.69 points from the third to fourth cycles. However, estimates of genetic parameters for records adjusted to a constant physiological age at mating were almost identical to those of unadjusted records. The data were not adjusted for physiological age at mating before calculation of the index. If this were done, it is unlikely that responses would have been much different because estimates of parameters essentially were unchanged.

\section{Discussion}

Realized cumulative selection differentials for the index ranged from .83 to .90 of expected values each generation (Table 4). The loss of potential selection resulted primarily from losses of females during surgery or abortions after surgery. The percentage of expected selection differentials that was realized tended to be greater in later than in early generations of the experiment. This can be 


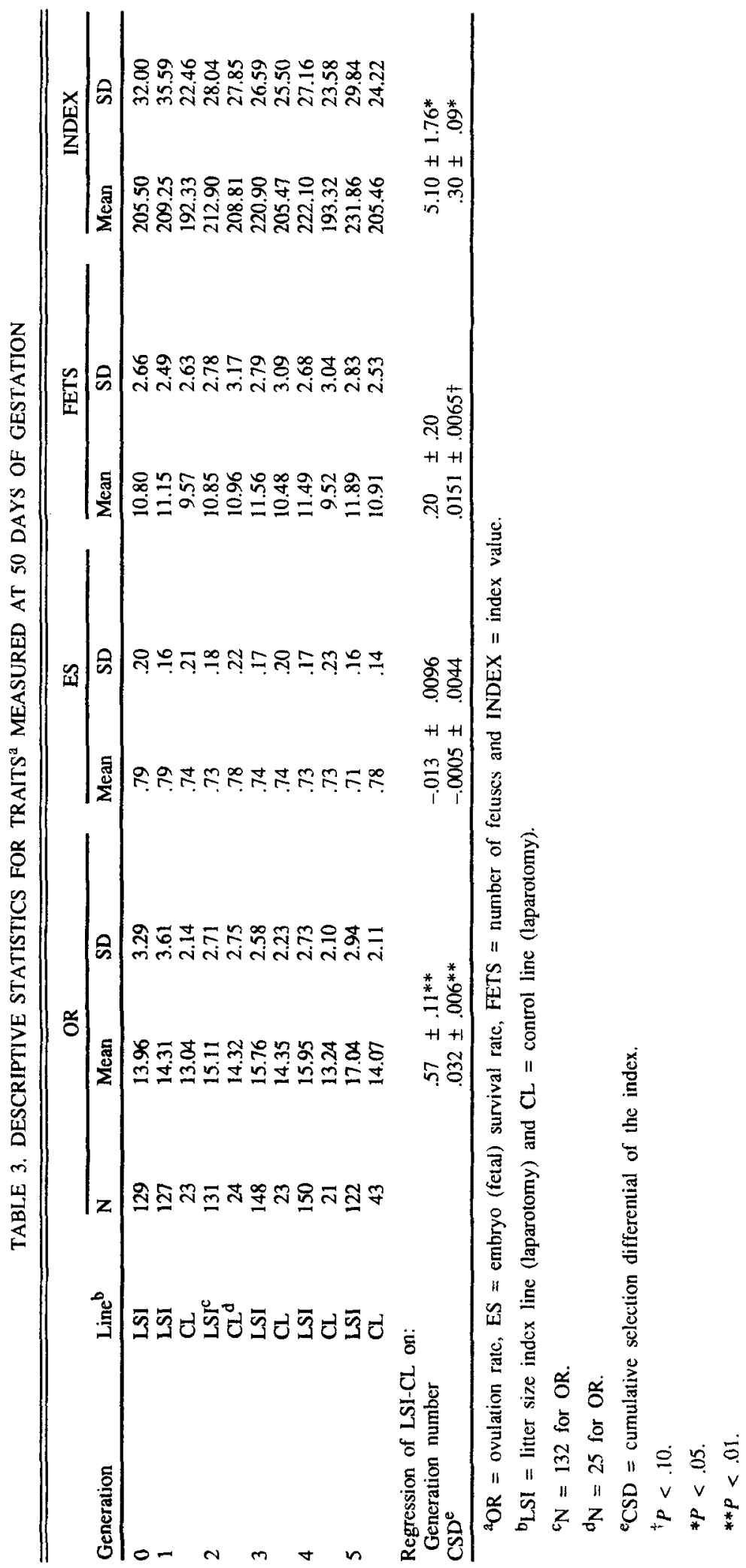




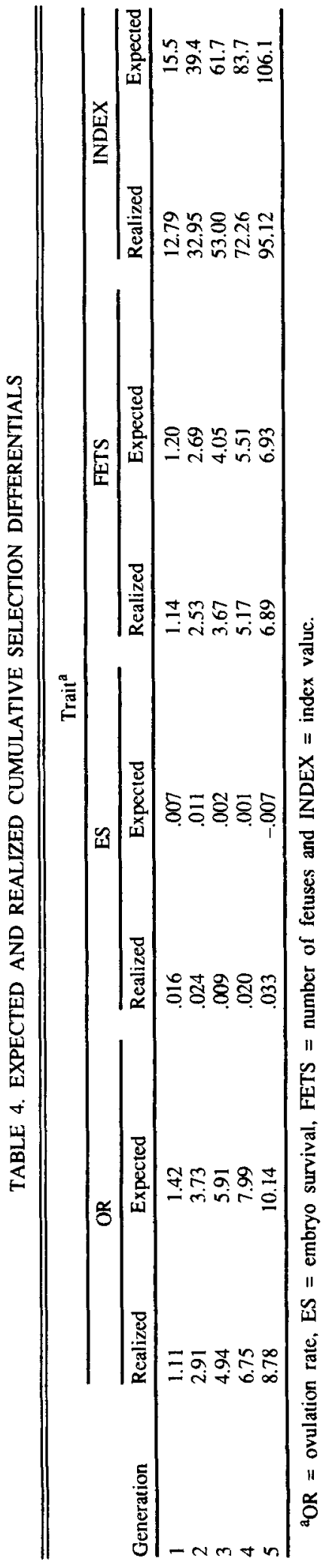

attributed to greater skill in the surgical technique.

Selection differentials for OR, FETS and ES (Table 4) are secondary or correlated selection differentials. The proportion of the potential selection that was realized was greater than $78 \%$ each generation for both OR and FETS. Realized selection differentials for ES actually were positive, whereas values near zero were expected. The difference was not larger, but females that indexed high due to high ES left more progeny than those that indexed high because of high $O R$ and average, or even below average, ES. At any rate, it did not appear that natural selection was opposing directional selection for the index.

Zimmerman and Cunningham (1975) reported a response of $.56 \pm .10$ ova per generation after five generations of selection for ovulation rate. This was nearly identical to the response of $.57 \pm .11$ ova per generation in our experiment. Selection rates among gilts were nearly identical in the two experiments. They reported a cumulative selection differential for females of 5.32 corpora lutea. We practiced selection in both sexes, whereas Zimmerman and Cunningham selected males randomly. Thus, we had higher selection differentials. Selection in our experiment was for an index that placed relatively more emphasis on ovulation rate than on embryo survival $(68: 32 \%)$, and the cumulative selection differential for this trait was 8.78 corpora lutea. This probably explains the similar rates of response even though ovulation rate was not selected for directly in our experiment and it was negatively correlated with the other trait in our index.

Cunningham et al. (1979) summarized results of nine generations of selection for ovulation rate. The response in ovulation rate averaged $.44 \pm .05$ ova per generation, but the correlated response in litter size was not significant (.06 \pm .07 piglets per generation). In our experiment the correlated response in litter size to selection for the index was larger (.19 \pm .14 piglets per generation), but again it was not significant.

In further analyses of the experiment in which selection was for ovulation rate, Johnson et al. (1984) found that selection for high ovulation rate resulted in a decline in embryo (fetal) survival rate of $-1.6 \pm .5 \%$ per generation. In this experiment survival rate to $50 \mathrm{~d}$ of gestation declined $-1.3 \pm .96 \%$ per generation even though it was included in the index. 
INDEX SELECTION FOR LITTER SIZE IN SWINE

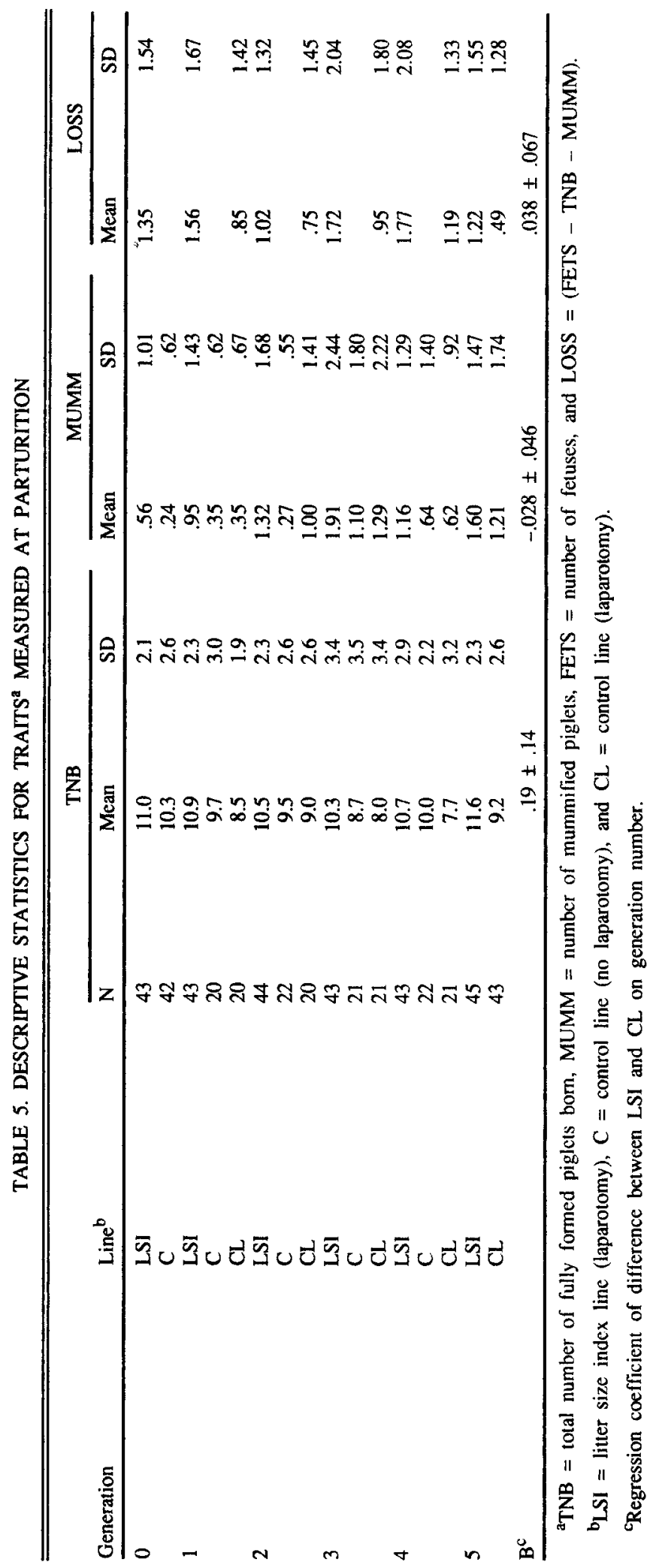


TABLE 6. ESTIMATES OF GENETIC PARAMETERS BY DAUGHTER-DAM REGRESSION ${ }^{\mathrm{a}}$

\begin{tabular}{llcll}
\hline & & & \multicolumn{2}{c}{ Genetic correlations } \\
\cline { 4 - 5 } Traii $^{\mathrm{b}}$ & $\mathrm{h}^{2}$ & SD $^{\mathrm{c}}$ & $\mathrm{ES}$ & \multicolumn{1}{l}{ FETS } \\
\hline OR & $.17 \pm .08$ & 2.89 & $-.56 \pm .24$ & $-.52 \pm .40$ \\
ES & $.18 \pm .09$ & .18 & & $.77 \pm .23$ \\
FETS & $.08 \pm .10$ & 2.73 & & \\
INDEX & $.12 \pm .09$ & 30.0 & & \\
\hline
\end{tabular}

${ }^{a} \mathrm{~N}=724$ daughter-dam pairs.

${ }^{\mathrm{b}} \mathrm{OR}=$ ovulation rate, $\mathrm{ES}=$ embryo survival, FETS $=$ number of fetuses and INDEX $=$ index value, all measured at $50 \mathrm{~d}$ of gestation.

'Pooled across year-line subclasses.

Johnson et al. (1984) presented genetic regression coefficients of component traits on the index based on parameters derived from the Nebraska experiment in which selection was for ovulation rate. These were used to predict response per generation for the selection differentials achieved in this experiment. Predicted responses were .80 eggs and -.019 points survival rate. Estimated genetic change was about $70 \%$ of predicted change for both OR (.57 eggs) and ES (-.013 points).

A correlation of 1.0 between number of fetuses at $50 \mathrm{~d}$ of gestation and litter size at birth was assumed, and predicted response in number born was .29 pigs per generation. The observed change in litter size was $.20 \pm .20$ at $50 \mathrm{~d}$ of gestation and $.19 \pm .14$ at birth. The agreement between these values indicates a fairly high genetic correlation between litter size at the two stages even though a sizeable loss in number of fetuses occurs late in gestation (Christenson et al., 1987).

Females in line LSI that farrowed represented a selected sample consisting entirely of high indexing gilts, most of which had large litters at $50 \mathrm{~d}$ of gestation. Lower survival rate after $50 \mathrm{~d}$ of gestation in these gilts than in control gilts was observed and probably was due to greater fetal death late in gestation and possibly to greater harmful effects of laparotomy in large litters than in average-sized litters.

The mean number born for the select line probably underestimates the potential litter size

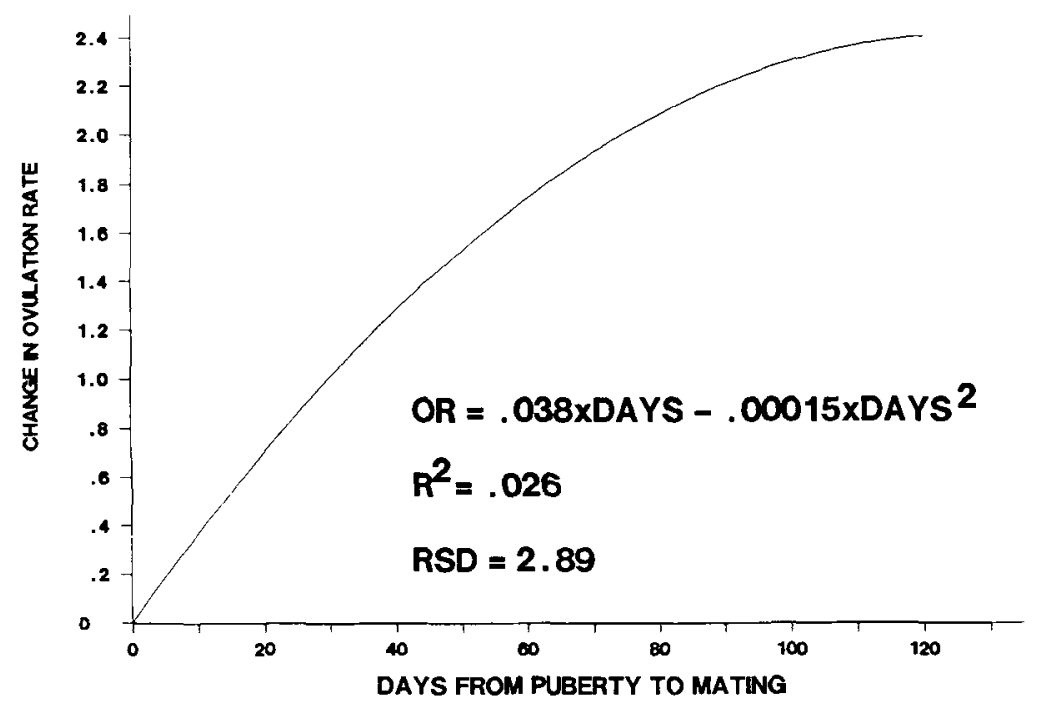

Figure 1. Change in ovulation rate with increased days from puberty to mating $\left(\mathbf{R}^{2}=\right.$ within year-line sums of squares explained by the model; $\mathrm{RSD}=$ residual $\mathrm{SD}, \mathrm{df}=892$. 


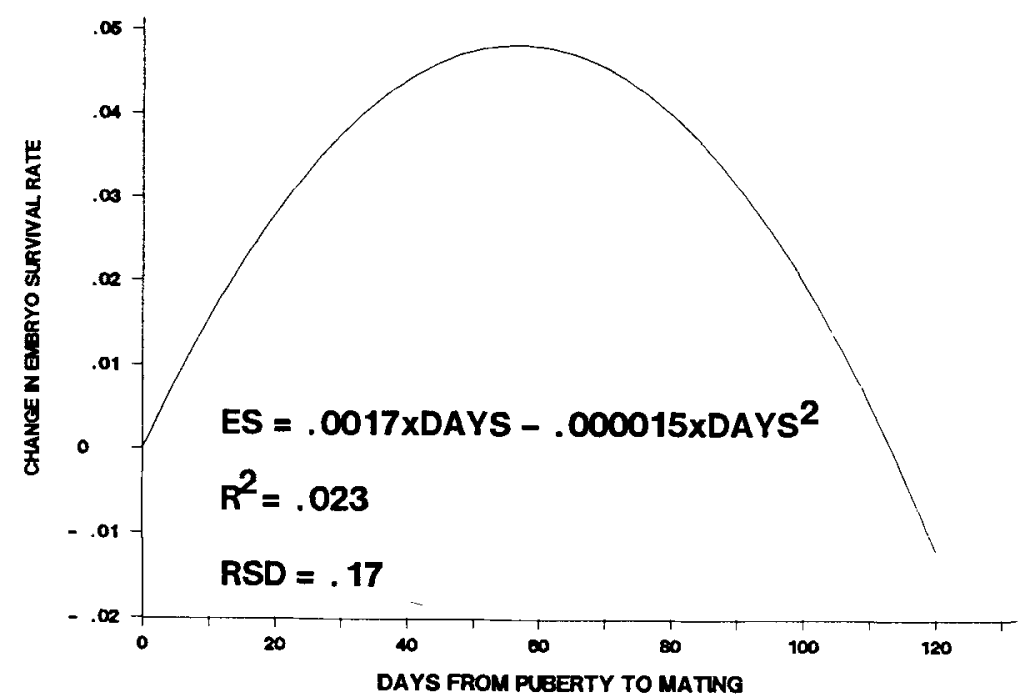

Figure 2. Change in embryo (fetal) survival rate with increased days from puberty to mating $\left(\mathrm{R}^{2}=\right.$ within year-line sums of squares explained by the model; $R S D=$ residual $\mathrm{SD}, \mathrm{df}=892$ ).

of selected gilts. Laparotomy reduced the number of fully formed piglets at birth in the control line and is assumed to have had a similar effect in the select line. There also were more mummified piglets in the select line than in the control line, but the explanation for this is not clear. Perhaps it is a natural phenomenon to have more mummified piglets in large litters. However, laparotomy may cause a greater incidence of mummified piglets in females with large litters than in those with average- or small-sized litters. The average difference in number of mummified piglets between control line females that were and those that were not laparotomized was $.23 \pm .18$. This gave some indication that laparotomy at $50 \mathrm{~d}$ of gestation increased the number of mummified piglets at birth.

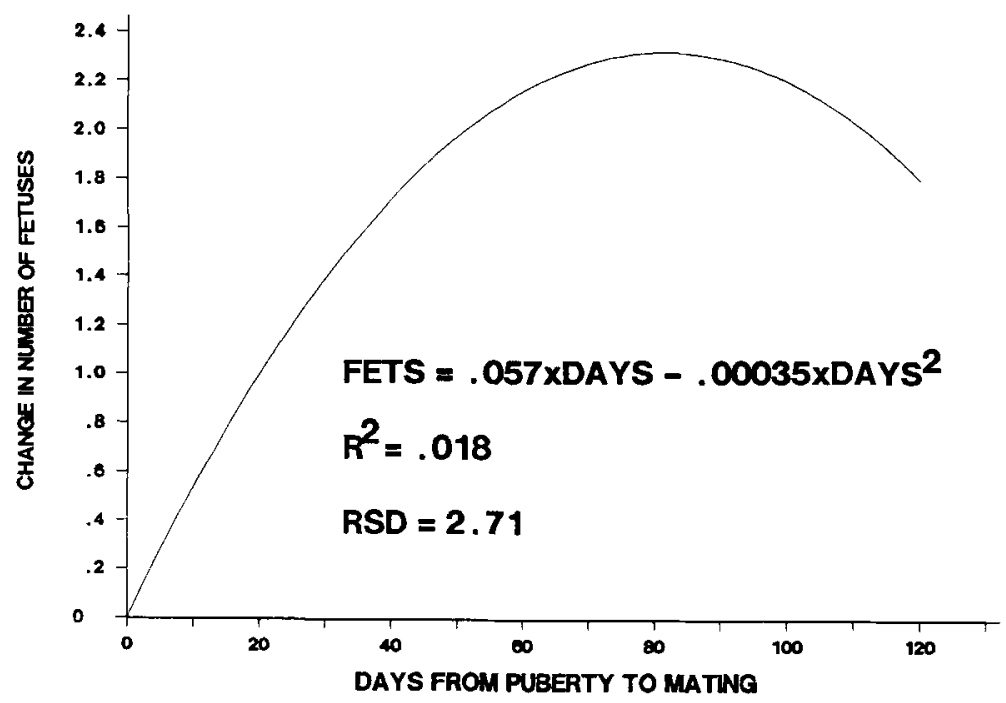

Figure 3. Change in number of fetuses at $50 \mathrm{~d}$ of gestation with increased days from puberty to mating $\left(R^{2}=\right.$ within yearline sums of squares explained by the model; $\mathrm{RSD}=$ residual $\mathrm{SD}, \mathrm{df}=892$ ). 


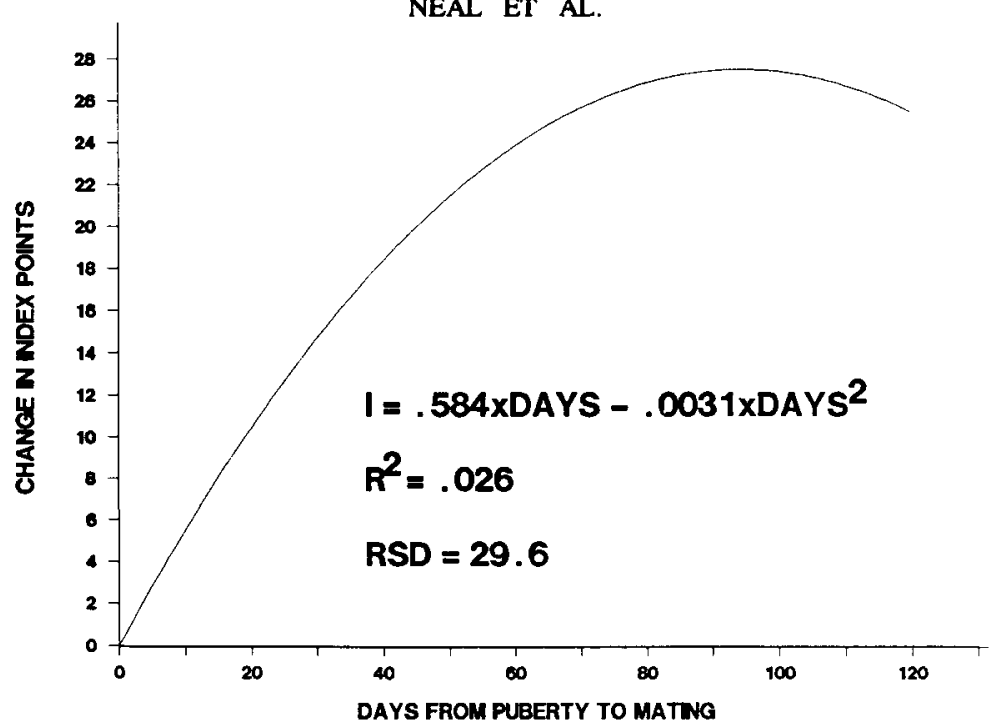

Figure 4. Change in index points with increased days from puberty to mating $\left(R^{2}=\right.$ within year-line sums of squares explained by the model; $\mathrm{RSD}=$ residual $\mathrm{SD}, \mathrm{df}=892$ ).

Clutter et al. (1987) reported the results of an experiment with mice that was very similar to our experiment. Selection was for an index of OR and embryo (fetal) survival rate. After five generations, the select line had .5 more fetuses than the control line at $17 \mathrm{~d}$ of gestation, a difference of approximately onehalf of the difference we observed at $50 \mathrm{~d}$ of gestation.

Direct selection for OR in mice (Bradford, 1969; Land and Falconer, 1969) was successful in increasing ovulation rate, although significant correlated responses in litter size were not observed. Improvements in litter size in mice have occurred from direct selection (Falconer, 1955, 1965, 1971; Bradford, 1968, 1979; Joakimsen and Baker, 1977; Bakker et al. 1978; Eisen and Durrant, 1980) and from selection for embryo (fetal) survival rate (Bradford, 1969, 1979). Responses from direct selection have been attributed largely to increased ovulation rate and stable or increasing survival rate (Bakker et al., 1978; Bradford, 1979).

The selection criterion for embryo survival in mice reported by Bradford (1969) was N/ $\mathrm{CL}$, weighted by $\mathrm{N}$. They chose this criterion to place positive selection pressure on both the ratio and $N$. The two traits are negatively correlated, and selection for N/CL alone naturally would have selected for fewer ovulations. The improvement in litter size was due to an increase in both survival rate and ovulation rate. The estimates of genetic correlations among traits at $50 \mathrm{~d}$ of gestation that we found are consistent with these responses. Ovulation rate was negatively correlated with ES and FETS, but FETS was quite highly correlated with ES.

Estimates of genetic parameters of the components of litter size in swine are sparse. Cunningham et al. (1979) reported a realized heritability for ovulation rate of $.42 \pm .06$. The estimate obtained by daughter-dam regression in the present experiment was lower (.17 \pm .07$)$. Johnson et al. (1984) derived estimates of genetic parameters for ES using data from the experiment in which selection was for ovulation rate. The values obtained were quite similar to the estimates from this experiment. No estimate of the heritability of number of fetuses at $50 \mathrm{~d}$ of gestation was found in the literature, but the value of .08 is similar to many estimates of the heritability of litter size at birth, which is generally accepted to be about .10. The estimate of the heritability of the index by daughter-dam regression was lower than the realized heritability of .30 .

Five generations of selection for an index of $O R$ and ES was effective in increasing index value and ovulation rate. Similar increases occurred for number of fetuses at $50 \mathrm{~d}$ of gestation and total number of fully formed piglets born, but neither increased significant- 
ly. Therefore, the rate of decline in embryo (fetal) survival rate did not completely offset the increase in ovulation rate. Christenson et al. (1987) reported that fetal loss is sizeable late in gestation. If some of the variation in this loss is genetic, selection for an index as in this experiment probably would be more effective if fetuses or piglets could be counted closer to or at farrowing time. However, it would be difficult to do laparotomies much later than $50 \mathrm{~d}$ of gestation and still remove cull gilts from the herd before parturition. This procedure was important in this experiment because it allowed more matings to be made than the number of farrowing spaces and allowed increased selection differentials.

Optimum weightings on the traits in the index depend on their genetic parameters, their relationships with litter size and their means (Johnson et al., 1984). The genetic parameters are not well known, and if selection is effective, the means change each generation. Leymaster et al. (1986) and Christenson et al. (1987) have proposed selection for litter size in unilaterally ovariectomized-hysterectomized females as a method to improve uterine capacity. In this model, ovulation rate and litter size are nearly independent and uterine capacity for one horn is measured as litter size at term. However, genetic parameters are still needed, optimum weightings on the components still change as the means change and the numbers evaluated cannot exceed the number of farrowing spaces if selection for litter size were done on an index of ovulation rate and uterine capacity in this model. Thus, with the same population size, selection intensities will be lower than in the present experiment. These methods and those used in this experiment need additional evaluation to fully understand the relationships between ovulation rate, embryo survival and uterine capacity and to determine how best to utilize variation among these traits to change litter size.

\section{Literature Cited}

Bakker, H., J. H. Wallinga and R. D. Politiek. 1978. Reproduction and body weight of mice after long-term selection for larger litter size. J. Anim. Sci. 46:1572.

Bradford, G. E. 1968. Selection for litter size in mice in the presence and absence of gonadotropin treatment. Genetics 58:283.

Bradford, G. E. 1969. Genetic control of ovulation rate and embryo survival in mice. I. Response to selection. Genetics 61:905.
Bradford, G. E. 1979. Genetic variation in prenatal survival and liter size. J. Anim. Sci. 49(Suppl. 2):66.

Christenson, R. K., K. A. Leymaster and L. D. Young. 1987. Justification of unilateral hysterectomy-ovariectomy as a model to evaluate uterine capacity in swine. $J$. Anim. Sci. 65:738.

Clutter, A. C., M. K. Nielsen and R. K. Johnson. 1987. Alternative methods of selection for litter size in mice: Results from six generations. J. Anim. Sci. 64(Suppl. 1):91.

Cunningham, P. J., M. E. England, L. D. Young and D. R. Zimmerman. 1979. Selection for ovulation rate in swine: Correlated response in litter size and weight. J. Anim. Sci. 48:509.

Eisen, E. J. and B. S. Durrant. 1980. Genetic and maternal environmental factors influencing litter size and reproductive efficiency in mice. J. Anim. Sci. 50:428.

Falconer, D. S. 1955. Patterns of response in selection experiments with mice. Cold Spring Harbor Symp. Quant. Biol. 20:178.

Falconer, D. S. 1965. Maternal effects and selection response. Proc. XIth Int. Congr. Genet. 3:763.

Falconer, D. S. 1971. Improvement of litter size in a strain of mice at a selection limit. Genet. Res. 17:215.

Falconer, D. S. 1981. Introduction to Quantitative Genetics. (2nd Ed.). Longman Inc., New York.

Hill, W. G. 1972.. Estimation of realized heritabilities from selection experiments. II. Selection in one direction. Biometrics 28:767.

Hill, W. G. 1974. Variability of responses to selection in genetic experiments. Biometrics 30:363.

Hill, W. G. 1977. Variation in response to selection: In; E. Pollak, O. Kempthome and T. B. Bailey (Ed.) Proc. Int. Conf.. Quant. Genet. pp 343-365. Iowa State Univ., Ames.

Joakimsen, O. and R. L. Baker. 1977. Selection for litter size in mice. Acta Agric. Scand. 27:301.

Johnson, R. K., D. R. Zimmerman and R. J. Kittok. 1984. Selection for components of reproduction in swine. Livest. Prod. Sci. 11:541.

Land, R. B. and D. S. Falconer, 1969. Genetic studies of ovulation rate in the mouse. Genet. Res. 13:25.

Leymaster, K. A., R. K. Christenson and L. D. Young, 1986. A biological model to measure uterine potential for litter size in swine. Proc. 3rd World Congr. Genet. Appl. Livest. Prod. 11:209.

Notter, D. R., G. E. Dickerson and J. A. DeShazer. 1976. Selection for rate and efficiency of lean gain in the rat. Genetics 84:125.

Ollivier, L. 1982. Selection for prolificacy in the pig. Pig News and Information 3:383.

Richardson, R. H., K. Kojima and H. L. Lucas. 1968. An analysis of short term selection experiments. Heredity $23: 493$.

Rutledge, J. J. 1980 . Fraternity size and swine reproduction. I. Effect on fecundity of gilts. J. Anim. Sci. 51:868.

Tess, M. W., G. L. Bennett and G. E. Dickerson. 1983. Simulation of genetic changes in iife cycle efficiency of pork production. II. Effects of components on efficiency. J. Anim. Sci. 56:354.

Zimmerman, D. R. and P. J. Cunningham. 1975. Selection for ovulation rate in swine: Population, procedures and ovulation response. J. Anim. Sci. 40:61. 